\title{
Resistance to Fire Blight among Flowering Pears and Quince
}

\author{
Andrew C. Bell, ${ }^{1}$ Thomas G. Ranney, ${ }^{2}$ and Thomas A. Eaker ${ }^{3}$ \\ Department of Horticultural Science, Mountain Horticultural Crops Research and \\ Extension Center, North Carolina State University, Fletcher, NC 28732-9244
}

\author{
Turner B. Sutton ${ }^{2}$ \\ Department of Plant Pathology, North Carolina State University, Raleigh, \\ NC 27695-7616
}

Additional index words. Chaenomeles spp., Erwinia amylovora, Pyrus spp., disease resistance, host plant resistance

\begin{abstract}
Fire blight, caused by the bacterium Erwinia amylovora (Burrill) Winslow et al., is one of the most destructive diseases of plants in the Rosaceae subfamily Maloideae. Artificial inoculations, using $E$. amylovora strain E2002a, were conducted to determine levels of resistance to fire blight among taxa of flowering pears (Pyrus L. spp.) and quince (Chaenomeles Lindl. spp.). The level of resistance was measured as the length of the fire blight lesion as a percentage of overall shoot length. Considerable variation in resistance was observed among both pears and quince. Pyrus ussuriensis Maxim. 'Prairie Gem' was highly resistant with a lesion length of $1 \%$ of the total shoot length. Pyrus calleryana Decne. 'Bradford' was intermediate with a $50 \%$ lesion length while $P$. calleryana 'Chanticleer' was significantly more resistant with a lesion length of $31 \%$. Nine pear taxa were highly susceptible and did not differ significantly from $100 \%$ disease severity (total shoot death). Chaenomeles speciosa (Sweet) Nak. 'Contorta' was highly resistant with a lesion length of $15 \%$. Six quince taxa, including $C$. x superba $($ Frahm) Rehd. 'Cameo', 'Texas Scarlet', and 'Jet Trail' were highly susceptible while nine other taxa showed intermediate resistance.
\end{abstract}

Flowering pears (Pyrus L. spp.) and flowering quince (Chaenomeles Lindl. spp.) are two genera in the Rosaceae subfamily Maloideae that include many species and hybrids with significant economic importance as nursery and landscape plants. Despite their popularity, cultivation of these genera can be difficult due to their susceptibility to fire blight.

The genus Pyrus consists of $\approx 22$ species whose native ranges extend from Europe and North Africa to across the Asian continent (Bell and Hough, 1986). In addition to being cultivated as a fruit crop, some species of pears

Received for publication 5 Jan. 2004. Accepted for publication 1 Apr. 2004. This research was funded, in part, by the North Carolina Agricultural Research Service (NCARS), Raleigh, U.S. Department of Agriculture, and the J. Frank Schmidt Family Charitable Foundation. The use of trade names in this publication does not imply endorsement by the NCARS of the products named nor criticism of similar ones not mentioned. Technical assistance of Sharon Williamson and staff of the Mountain Horticultural Crops Research Station is greatly appreciated. The authors wish to thank Don Shadow, Ken Tilt, the Arnold Arboretum, and the Landscape Plant Development Center for providing plant material and Jay Norelli and Herb Aldwinckle who generously provided the isolate of Erwinia amylovora used for inoculum. From a dissertation submitted by Andrew Bell in partial fulfillment of the requirements for the $\mathrm{PhD}$ degree.

${ }^{1}$ Corresponding author and former graduate teaching assistant. Currently: Associate director, North Carolina Botanical Garden, University of North Carolina, Chapel Hill, N.C.; e-mail bell@unc.edu.

${ }^{2}$ Professor.

${ }^{3}$ Research specialist. are frequently used as landscape plants. For example, the callery pear (Pyrus calleryana Decne.) is one of the most common flowering trees used in landscape horticulture. The most notable and widely planted cultivar of callery pear is 'Bradford', which was introduced by the U.S. Department of Agriculture in the early 1960s. 'Bradford' and other cultivars of callery pear offer many desirable landscape qualities including early spring flowering, broad adaptability, excellent resistance to arthropod pests, and outstanding fall color. The popularity and use of flowering pears as landscape plants has increased significantly in recent decades.

The genus Chaenomeles consists of three species, two of which are native to China while the third is restricted to Japan. The flowering quince is closely related to pears, apples (Malus Mill. spp.), and the true quince (Cydonia Mill. spp.). Unlike its close relatives, flowering quince is not commonly cultivated as a fruit crop. However, Weber (1964) reported that the flowering quince has been cultivated for $>400$ years and that $>500$ cultivars have been named and propagated. Today, numerous cultivars of flowering quince are readily available in the horticultural industry. The flowering quince is highly prized as an early flowering shrub and is commonly used in landscapes.

Fire blight is a highly destructive disease caused by the bacterium Erwinia amylovora (Burrill) Winslow et al. This disease can be especially problematic in regions where environmental conditions for disease development are favorable, specifically where springtime weather is warm and wet (van der Zwet and Keil, 1979). Susceptible plants can be severely damaged or killed by fire blight in both nursery and landscape plantings. The economic importance and history of pears as a fruit crop has resulted in numerous attempts to document resistance among species and cultivars. van der Zwet and Keil (1979) summarized relative susceptibility of five important species of pears to fire blight. Furthermore, they provided fire blight resistance ratings for $>400$ cultivars of pear fruit trees based on an extensive survey of the literature.

There have been few attempts to document resistance to fire blight among flowering pears. Fare et al. (1991) and McNeil et al. (1986) reported resistance ratings for selected cultivars of Pyrus calleryana. Both studies reported 'Redspire' and 'Aristocrat' as being more susceptible than 'Bradford', 'Capital', 'Fauriei', and 'Whitehouse'. Because the incidence of fire blight can be sporadic and vary from region to region and year to year, observations and results from field surveys can be inconsistent and highly variable. Plants that initially appear to be resistant may later be found to be susceptible when conditions are favorable for disease development. In the aforementioned studies, artificial inoculations were not used and neither study documented which strain(s) of $E$. amylovora were present.

There is limited information on resistance to fire blight among taxa of flowering quince. Based on their survey of the literature, van der Zwet and Keil (1979) listed only one species, Chaenomeles japonica (Thunb.) Spach., and reported that it was very susceptible to blossom blight and moderately susceptible to twig blight.

Despite commercial importance to landscape horticulture, extensive information on fire blight resistance among flowering pears and quince is not readily available. Ornamental plant breeding programs could benefit greatly from screening studies that use specific clones and artificial inoculations. Artificial inoculations of actively growing shoots with virulent strains of E. amylovora provide an effective and consistent means for evaluating fire blight resistance (Aldwinckle and Preczewski, 1979). Therefore, the objective of this study was to determine levels of resistance to fire blight among a variety of flowering pear and quince taxa using artificial inoculations.

\section{Materials and Methods}

Pears. Twenty-seven taxa (Table 1) of containerized pears, arranged in a randomized complete block design with 4 to 12 replications, were screened for fire blight resistance using artificial inoculations at the Mountain Horticultural Crops Research Station, Fletcher, N.C. This study included cultivars, clonal selections, and hybrids of $P$. amygdaliformis Vill., P. betulifolia Bunge., P. calleryana, P. elaeagrifolia Pall., P. fauriei Schneid., P. koehnei Schneid., P. nivalis Jacq., P. pyrifolia (Burm.) Nak., $P$. regelii Rehd., P. salicifolia Pall., and $P$. ussuriensis Maxim. All taxa were 1-year budded plants on $P$. calleryana rootstocks grown in 14.2-Lcontainers. Container substrate was 5 pine bark : 1 peat (by volume) amended 
with $3 \mathrm{~kg} \cdot \mathrm{m}^{-3}$ micronutrients (Esmigran, The Scotts Co., Marysville, Ohio) and $5.3 \mathrm{~kg} \cdot \mathrm{m}^{-3}$ dolomitic limestone. Plants were placed in a lath house under 50\% shade in April 2000 and fertilized with $50 \mathrm{~g}$ controlled-release fertilizer (Osmocote Plus, 15-9-12, The Scotts Co., Marysville, Ohio). Irrigation was applied as necessary.

The isolate of E. amylovora used in this study was strain (E2002a). This strain has previously been categorized and used to screen advanced selections of pears for resistance to fire blight (R.L. Bell, 1999, unpublished data and personal communication). The inoculum was prepared from $24 \mathrm{~h}$ cultures grown on nutrient agar plates at $26{ }^{\circ} \mathrm{C}$. The cultures were rinsed with distilled water and bacterial suspension collected. The inoculum was adjusted to a concentration of $\approx 1 \times 10^{7}$ colony forming units $(\mathrm{cfu}) / \mathrm{mL}$. One to two actively growing shoots (subsamples) per tree were inoculated in May 2000. The two youngest leaves were bisected with a pair of scissors that had been dipped into the inoculum prior to each cut. The disease lesion length and total length of the current season's growth of the inoculated shoot were measured $40 \mathrm{~d}$ following inoculation. The severity of infection was expressed as the length of the fire blight lesion as a percentage of overall shoot length. All data were subjected to analysis of variance procedures after arc-sin transformation. Means for percent lesion length were separated by the Waller-Duncan test.

Quince. Twelve taxa (Table 2) of flowering quince were screened for fire blight resistance in May 2001. This study included taxa of $C$. cathayensis (Hemsl.) Schneid., C. japonica, C. speciosa (Sweet) Nak., and C. x superba (Frahm) Rehd. Plant material consisted of 1-year-old container-grown rooted cuttings. Growing conditions, plant care, experimental design, inoculation procedure, and data analysis were conducted as described above. Inoculum for this study was E. amylovora strain E2002a $\left(\approx 2 \times 10^{8}(\mathrm{cfu}) / \mathrm{mL}\right)$.

\section{Results}

Pears. The taxa included in this study showed considerable variation in resistance to fire blight with the severity of infection ranging from $1 \%$ to $100 \%$ of the current season's shoot growth (Table 1). Ten taxa were highly susceptible with a percent length $>85 \%$. The susceptible taxa included specific clones of $P$. elaeagrifolia, P.fauriei, P. koehnei, P. nivalis, P. pyrifolia, and $P$. salicifolia as well as a number of advanced hybrid selections. At the other extreme, two taxa, P. ussuriensis 'Prairie Gem' and Pyrus 950104, a clone derived from open pollination of a $P$. calleryana $\times P$. betulifolia hybrid, were highly resistant with minimal disease development. Fifteen other taxa were intermediate with lesion length ranging from $16 \%$ to $81 \%$ of the annual shoot growth.

Quince. The taxa included varied significantly in resistance to $E$. amylovora strain E2002a(Table 2). Among the flowering quince taxa, C. speciosa 'Contorta' was highly resistant with a mean lesion length of $15 \%$. Six of

Table 1. Fire blight ratings for taxa of flowering pears (Pyrus spp.) based on artificial inoculation.

\begin{tabular}{|c|c|}
\hline $\begin{array}{l}\text { Pyrus } \\
\text { taxa } \\
\end{array}$ & $\begin{array}{l}\text { Disease severity } \\
(\% \text { lesion length })^{z}\end{array}$ \\
\hline P. salicifolia 'Pendula' & $100 \mathrm{a}$ \\
\hline 93-8-5' (P. fauriei $\times$ P. salicifolia 'Pendula') & $98 \mathrm{a}$ \\
\hline P. nivalis & $97 \mathrm{ab}$ \\
\hline P. koehnei & $97 \mathrm{ab}$ \\
\hline P. pyrifolia & $95 \mathrm{abc}$ \\
\hline 93-32-4y (P. salicifolia 'Pendula' $x$ P. ussuriensis) & $94 \mathrm{abc}$ \\
\hline $911010^{y}(P$. ussuriensis $\times$ P. nivalis $)$ & $92 \mathrm{abc}$ \\
\hline P. elaeagrifolia 'Turkish Mist' & $91 \mathrm{abc}$ \\
\hline P. fauriei 'Korean Sun' & $89 \mathrm{abc}$ \\
\hline $93-2-2^{y}((P$. calleryana $\times P$. fauriei $) \times P$. nivalis $)$ & $87 \mathrm{abc}$ \\
\hline 93-17-3y (P. elaeagrifolia $\times$ P. amygdaliformis) & $81 \mathrm{~cd}$ \\
\hline P. calleryana 'Red Spire' & $69 \mathrm{de}$ \\
\hline P. calleryana 'Aristocrat' & $65 \mathrm{ef}$ \\
\hline 91-53-1'y $(P$. calleryana 'Chantcleer' $\times$ P. betulifolia $)$ & $63 \mathrm{ef}$ \\
\hline P. calleryana 'Whitehouse' & $62 \mathrm{efg}$ \\
\hline P. calleryana 'Bradford' & $50 \mathrm{fgh}$ \\
\hline P. calleryana 'Fauriei' & $46 \mathrm{ghi}$ \\
\hline 93-15-1 $($ P. elaeagrifolia $\times$ P. ussuriensis $)$ & 44 hij \\
\hline $911014^{y}(P$. usseriensis $\times$ P. regelii) & $42 \mathrm{hij}$ \\
\hline 91-42-1 $(P$. amydaliformis $\times$ P. regelii $)$ & $38 \mathrm{hij}$ \\
\hline 93-61-1' (P. amygdaliformis $\times$ P. calleryana 'Chanticleer') & $32 \mathrm{ijk}$ \\
\hline P. calleryana 'Chanticleer' (syn. 'Cleveland Select') & $31 \mathrm{jkl}$ \\
\hline P. regelii & $22 \mathrm{kl}$ \\
\hline 93-70-2y (P. calleryana 'Chanticleer' $\times$ P. elaeagrifolia $)$ & $22 \mathrm{kl}$ \\
\hline P. betulifolia 'Dancer' & $16 \mathrm{~lm}$ \\
\hline P. ussuriensis 'Prairie Gem' & $3 \mathrm{~m}$ \\
\hline $950104^{y}(P$. calleryana $\times P$. betulifolia $)$ & $1 \mathrm{~m}$ \\
\hline
\end{tabular}

Interspecific hybrid taxa.

${ }^{2}$ Percentage lesion length $=[$ length of fire blight lesion $(\mathrm{cm})] /[$ total shoot length $(\mathrm{cm})]$. Percent lesion lengths followed by same letter did not differ significantly $(P<0.05)$ according to Waller-Duncan's test on arc-sin transformed data.

the 12 taxa were highly susceptible with percent lesion length $>85 \%$. Five taxa were intermediate in susceptibility; C. speciosa 'Nivalis' was the least susceptible of this group while C. speciosa 'Mandarin' the most with lesion length of $37 \%$ and $68 \%$ respectively.

\section{Discussion}

Pears. Cultivars of $P$. calleryana differed significantly in their susceptibility to fire blight with $P$. calleryana 'Chanticleer' (syn. 'Cleveland Select') being more resistant to fire blight than P. calleryana 'Bradford', 'Whitehouse', 'Aristocrat', and 'Red Spire'. Our results were in general agreement with studies by Fare et al. (1991) and McNeil et al. (1986) in which 'Bradford', 'Fauriei', and 'Whitehouse' showed greater resistance than 'Aristocrat' and 'Redspire' under conditions of natural infection. However, in this study, 'Whitehouse' was not significantly more resistant than either 'Aristocrat' or 'Red Spire'. Overall, 'Chanticleer' was the most resistant commercially available cultivar of callery pear included in this study. Pyrus betulifolia 'Dancer' and a clone of $P$. regelii exhibited a level of resistance similar to that of $P$. calleryana 'Chanticleer'.

The genetic diversity that exists within the genus Pyrus has been exploited for fruit tree breeding; however, many of these taxa also possess desirable ornamental characteristics. Some species vary in flowering time, heat and cold tolerance, leaf shape, tree form, and disease resistance. While considerable variation in resistance to fire blight exists in all species of pears, P. ussuriensis and P. calleryana have been reported to exhibit the most
Table 2. Fire blight ratings for taxa of flowering quince (Chaenomeles spp.) based on artificial inoculation.

\begin{tabular}{lc}
\hline $\begin{array}{l}\text { Chaenomeles } \\
\text { taxa }\end{array}$ & $\begin{array}{c}\text { Disease severity } \\
\text { (\% lesion length) }\end{array}$ \\
\hline C. x superba 'Jet Trail' & $98 \mathrm{a}$ \\
C. speciosa 'Toyo-Nishiki' & $96 \mathrm{a}$ \\
C. x superba 'Texas Scarlet' & $95 \mathrm{a}$ \\
C. x superba 'Cameo' & $91 \mathrm{a}$ \\
C. aponica 'Sargentii', & $89 \mathrm{a}$ \\
C. speciosa 'Spitfire' & $88 \mathrm{a}$ \\
C. speciosa 'Mandarin' & $68 \mathrm{~b}$ \\
C. cathayensis & $62 \mathrm{bc}$ \\
C. speciosa 'Dragon's Blood' & $56 \mathrm{bcd}$ \\
C. x superba 'Crimson and Gold' & $40 \mathrm{~cd}$ \\
C. speciosa 'Nivalis' & $37 \mathrm{de}$ \\
C. speciosa 'Contorta' & $15 \mathrm{e}$ \\
\hline
\end{tabular}

zPercentage lesion length $=[$ length of fire blight lesion $(\mathrm{cm})] /[$ total shoot length $(\mathrm{cm})]$. Percent lesion lengths followed by same letter did not differ significantly $(P<0.05)$ according to Waller-Duncan's test on arc-sin transformed data.

fire blight resistance (van der Zwet and Keil, 1979). The study reported herein included clonal selections of these species. One clone, P. ussuriensis 'Prairie Gem', was found to be very resistant.

The hybrid taxa included in this study were provided by the Landscape Plant Development Center, Chanhassen, Minn. The Center's ornamental pear breeding program has been successful in obtaining many new hybrid plants by using a very diverse group of species as breeding parents (Hummel, 2000). Promising selections have been identified based on desirable ornamental characteristics, but no data regarding their resistance to fire blight have been recorded. One hybrid, Pyrus 950104, from this program was found to be very resistant to this virulent strain of E. amylovora. Pyrus 
93-70-2 and 93-61-1 were significantly more resistant than 'Bradford', the industry standard for resistance.

Cultivars of $P$. calleryana are among the most widely planted flowering trees in much of the United States. Despite their popularity, these plants are often short lived in the landscape. Some cultivars are very weak wooded, have poor branch arrangement, and are susceptible to fire blight. Genetic diversity and interspecific crossability in the genus $P y$ rus has lead to the development of many new hybrid plants. The success of new hybrids is, in part, dependent on their resistance to fire blight. Results from this study document the variation in resistance that exists among many taxa of flowering pears.

Quince. There is very limited information available on resistance to fire blight among taxa of flowering quince; however, C. japonica has been documented as being susceptible to blossom infection (van der Zwet and Keil, 1979). Many cultivars of flowering quince are highly prized for their very early spring flowers, which are present when environmental conditions are too cool for disease development. Many susceptible plants may escape primary infection (blossom blight) due to their flowering habit. Secondary infection (twig and leaf blight) and blossom infection on sporadic blooms typically occurs later in the growing season when environmental conditions are favorable for disease development.

This study included a number of cultivars of flowering quince that are common and important to the horticultural industry. Only one cultivar, C. speciosa 'Contorta' was highly resistant. Chaenomeles speciosa 'Nivalis' and $C$. x superba 'Crimson and Gold' were moderately resistant $(<50 \%$ lesion length). Although a number of taxa in this study are very susceptible, they may escape infection in some years due to the erratic nature of this disease (van der Zwet and Keil, 1979).

This research used artificial inoculations which provide the most effective means to evaluate resistance to fire blight. Significant variation in resistance among flowering pears and quince was observed and highly resistant taxa were identified. Information from this study provides a basis for the selection and improvement of flowering pears and quince with superior disease resistance.

\section{Literature Cited}

Aldwinckle, H.S. and J.L. Preczewski. 1979. Reaction of terminal shoots of apple cultivars to invasion by Erwinia amylovora. Phytopathology 66:1439-1444.

Bell, R.L. and L.F. Hough. 1986. Interspecific and intergeneric hybridization of Pyrus. HortScience 21:62-64.

Fare, D.C., C.H. Gilliam, and H.G. Ponder. 1991. Fire blight susceptibility, growth, and other characteristics in ornamental pears in Alabama. J. Arboricult. 17:257-260.

Hummel, R. 2000. Update on the landscape plant development center Pyrus breeding project: Promising selections. Proc. $11^{\text {th }}$ METRIA Conf. 19 Feb. 2003. <http://www.ces.ncsu. edu/fletcher/programs/nursery/metria/metria11/ hummel/pears.htm>

McNeil, R.E., J.R. Hartman, and W.D. Dunwell. 1986. Relative susceptibility of flowering pear (Pyrus calleryana) to fire blight (Erwinia amylovora) during the severe 1986 epiphytotic in Kentucky. Proc. S. Nursery Assn. Res. Conf., 31st Annu. Rpt. p. 156-159.

van der Zwet, T. and H.L. Keil. 1979. Fire blight: A bacterial disease of rosaceous plants. USDA Agr. Hdbk. 510.

Weber, C. 1964. The genus Chaenomeles (Rosaceae). J. Arnold Arboretum 45:160-345. 